\title{
Interferon gamma immunoreactivity in iris nerve fibres during endotoxin induced uveitis in the rat
}

\author{
Peizeng Yang, Alex F de Vos, Aize Kijlstra
}

\begin{abstract}
Aims-Previous studies have implied that interferon gamma (IFN- $\gamma$ ) is involved in the pathogenesis of endotoxin induced uveitis (EIU) in the rat. This study investigated the source of IFN- $\gamma$ in the iris during EIU.

Methods-Whole mounts of iris were isolated from Lewis rats before and at different times (from 4 hours to 14 days) after foot pad injection of $200 \mu \mathrm{g}$ Salmonella typhimurium lipopolysaccharide (LPS). Immunohistological analysis was performed using monoclonal antibodies (mAbs) specific to rat IFN- $\gamma$ (DB12 and DB13). mAbs specific to monocytes, macrophages, and dendritic cells and MHC class II were used to asses the inflammatory response in the eye (ED-1, ED-2, and OX-6). An antibody specific to neurofilaments (2H3) was used to stain nerve fibres in the normal iris.
\end{abstract}

Results-LPS administration induced acute intraocular inflammation, characterised by a massive infiltration of monocytes/macrophages and increased numbers of MHC class II positive cells in the iris. IFN- $\gamma$ immunoreactive cells were not detected in iris whole mounts of control rats. Strikingly, IFN- $\gamma$ immunoreactivity was found in fibres from 4 hours until 10 days after LPS injection, with the most intense staining at 48-72 hours. Other DB12 or DB13 positive cells were not detected in the iris. The pattern of DB12 and DB13 staining in the inflamed iris was similar to the $2 \mathrm{H} 3$ staining of neurons in the iris of control rats.

Netherlands

Ophthalmic Research Institute, Amsterdam, Netherlands

P Yang

A F de Vos

A Kijlstra

Zhongshan

Ophthalmic Centre, Guangzhou, PR China

P Yang

University of

Amsterdam,

Netherlands

A Kijlstra

Correspondence to: Prof dr A Kijlstra,

Netherlands Ophthalmic

Research Institute, PO Box

12141, 1100 AC Amsterdam, Netherlands.

Accepted for publication 9 January 1998
Conclusion-These results show that systemic LPS administration induces IFN- $\gamma$ immunoreactivity in iris fibres and suggest that iris nerve fibres may be a source of IFN- $\gamma$ during EIU. The IFN- $\gamma$ immunoreactive material in the iris nerve fibres may be identical to neuronal IFN- $\gamma$.

(Br F Ophthalmol 1998;82:695-699)

Interferon gamma (IFN- $\gamma$ ) plays an important role in the regulation of immune and inflammatory responses and in the host defence against viral infections. It has multiple biological effects, including activation of monocytes/ macrophages and polymorphonuclear cells, proliferation of Th1-type lymphocytes, induction of cytokines, such as interleukin 1 (IL-1) and tumour necrosis factor- $\gamma$ (TNF), induction of nitric oxide (NO) production, induction of MHC antigen expression on a wide variety of cell types, including lymphocytes and macrophages, and antiviral activity (reviewed by Young and Hardy ${ }^{1}$ and Sen $^{2}$ ).

The production of IFN- $\gamma$ is mainly restricted to T lymphocytes and natural killer (NK) cells. $\mathrm{T}$ lymphocytes secrete IFN- $\gamma$ in response to appropriate antigens or mitogens. Both $\mathrm{T}$ cells and NK cells are readily stimulated to produce IFN- $\gamma$ by the cytokines IL-2 and IL-12, whereas corticosteroids, transforming growth factor (TGF- $\beta$ ), and IL-10 markedly suppress its synthesis. ${ }^{2}$ Using monoclonal antibodies against rat IFN- $\gamma$ it was recently shown that neurons in peripheral ganglia contain IFN- $\gamma$ immunoreactive molecules. ${ }^{34}$ This material has now been further characterised and has been denoted as neuronal IFN- $\gamma \cdot{ }^{3-5}$ It differs from "immune" IFN- $\gamma$ in that it has a much higher molecular weight (between 54 and 66 $\mathrm{kD})$ but is similar in bioactivity concerning antiviral effects and MHC inducing capacities. $^{5}$

Several studies have implied that IFN- $\gamma$ is involved in the pathogenesis of endotoxin induced uveitis (EIU), although its exact contribution remains unclear. IFN- $\gamma$ mRNA was detected in the uvea ${ }^{67}$ and protein was found in aqueous humour ${ }^{8}$ during EIU. Injection of IFN- $\gamma$ into the eyes of rats induced uveitis that resembled the response to lipopolysaccharide (LPS) (reviewed by De Vos et $a l^{9}$ ) and transgenic mice expressing IFN- $\gamma$ in the eye developed profound intraocular inflammation, ${ }^{10}{ }^{11}$ indicating that this cytokine may have uveitogenic properties. Strikingly, systemic administration of anti-IFN- $\gamma$ antibodies resulted in an exacerbation of EIU. ${ }^{12}$ Moreover, Whitcup et al showed recently that the beneficial effect of intraocular IL-12 treatment on EIU was associated with increased levels of aqueous IFN- $\gamma .{ }^{8}$ It has been hypothesised that the "paradoxical" effects of IFN- $\gamma$ in EIU may be concentration dependent. ${ }^{8}$

The present study investigated the source of IFN- $\gamma$ in the iris during EIU in the rat. Earlier attempts, using immunohistochemical analysis of tissue sections, did not reveal IFN- $\gamma$ positive cells in the eye during EIU. ${ }^{13}$ Previously, we have used immunohistochemical analysis of tissue whole mounts to assess cellular changes in the retina and choroid during EIU ${ }^{14}{ }^{15}$ and noted the higher resolution of this technique compared with the former. In the study presented here, we show IFN- $\gamma$ immunoreactivity is expressed in iris nerve fibres during endotoxin induced uveitis.

\section{Materials and methods}

EXPERIMENTAL PROTOCOL

Inbred male Lewis rats (6-8 weeks of age), weighing 150-200 g, were purchased from 

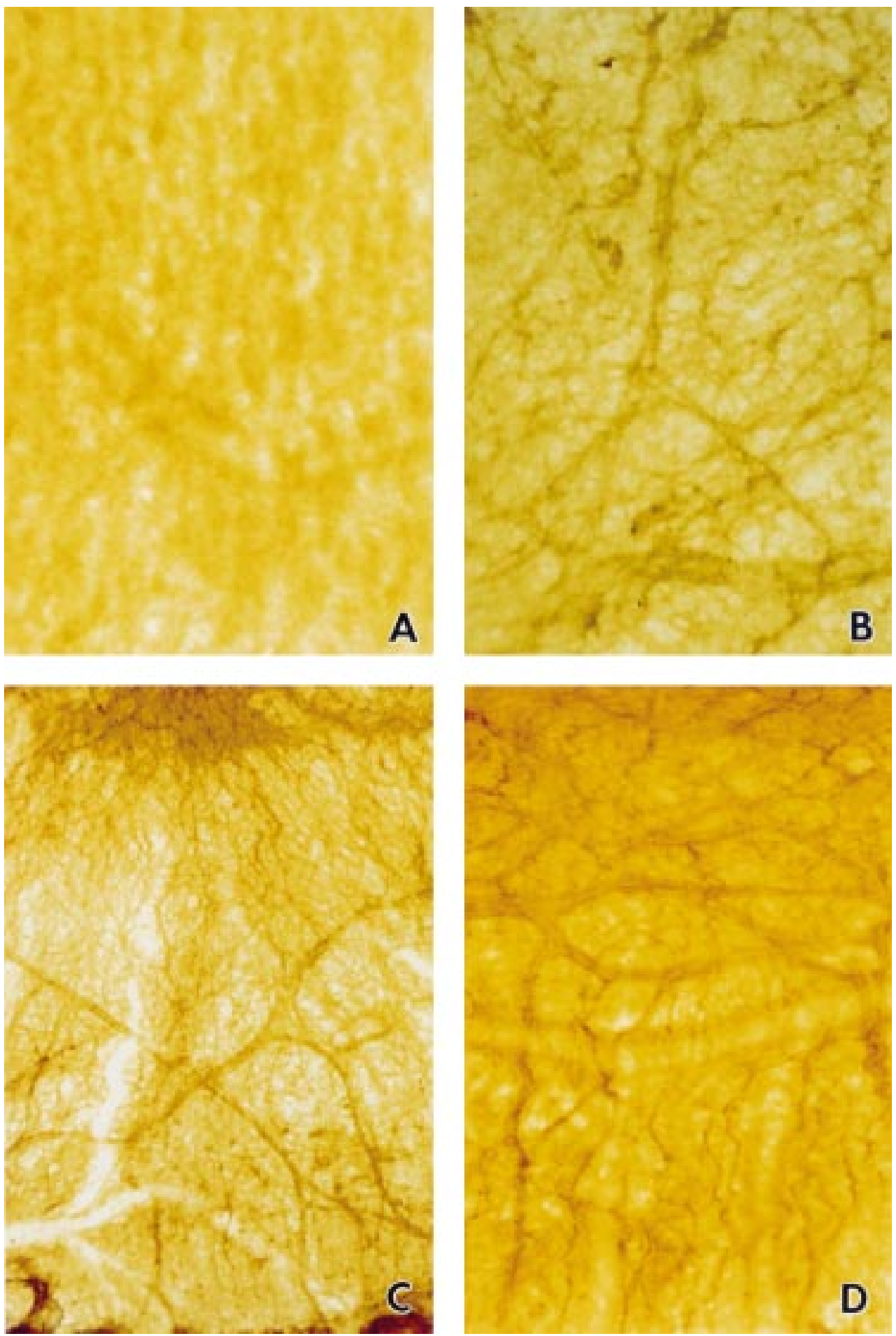

Figure 1 Immunohistochemical staining of iris whole mounts with $m A$ bs $D B 12$ ( $A$ and $B)$ and DB13 (C and D). Iris whole mounts used were isolated from a control rat $(A)$ and at 24 hours $(B), 48$ hours $(C)$, and 72 hours $(D)$ after LPS injection. Original magnifications, $A \times 250 ; B \times 250 ; C \times 63$; and $D \times 100$.

Harlan (Zeist, Netherlands). All rats were treated according to the ARVO resolution on the use of animals in research. Salmonella typhimurium LPS (Difco, Detroit, MI, USA) was dissolved in sterile pyrogen free saline $0.9 \%$ at a concentration of $2 \mathrm{mg} / \mathrm{ml}$ and $50 \mu \mathrm{l}$ was injected into both hind foot pads of rats, the total dose of LPS per animal being $200 \mu \mathrm{g} .{ }^{14}$ Before the enucleation of eyes, rats were injected with 1500 IU intravenous heparin and perfused with $250 \mathrm{ml}$ cold phosphate buffered saline (PBS, pH 7.4) via the left ventricle during systemic anaesthesia, as previously described. ${ }^{14}$ Eyes were enucleated at different times-that means, before LPS injection (normal controls) and 4, 8, 16, 24, 48, 72, 96 hours and 7, 10, and 14 days after LPS injection. Enucleated eyes were dissected 
Table 1 Frequency of neuronal IFN- $\gamma$ staining in the iris of control rats and of rats after systemic lipopolysaccharide injection

\begin{tabular}{lcc}
\hline Time (hours) & $\begin{array}{l}\text { No of DB12 } \\
\text { positive irides/total } \\
\text { No of irides (\%) }\end{array}$ & $\begin{array}{l}\text { No of DB13 } \\
\text { positive irides/total } \\
\text { No of irides (\%) }\end{array}$ \\
\hline 0 & $0 / 6$ & $0 / 7$ \\
4 & $0 / 6$ & $1 / 7(17)$ \\
8 & $0 / 8$ & $1 / 6(17)$ \\
16 & $4 / 10(40)$ & $3 / 6(50)$ \\
24 & $9 / 17(53)$ & $7 / 12(58)$ \\
48 & $5 / 9(55)$ & $12 / 12(100)$ \\
72 & $5 / 6(83)$ & $6 / 8(75)$ \\
96 & $1 / 4(25)$ & $3 / 4(75)$ \\
7 days & $1 / 4(25)$ & $2 / 3(67)$ \\
10 days & $0 / 2$ & $1 / 2(50)$ \\
14 days & $0 / 2$ & $0 / 2$ \\
\hline
\end{tabular}

behind the ciliary body after which the lens together with remaining vitreous fluid was removed from the anterior part. The iris ciliary body was carefully separated from the sclera and fixed in cold $100 \%$ ethanol for 5 minutes. Fixed iris ciliary body whole mounts were placed in PBS and stored at $4^{\circ} \mathrm{C}$ until use.

IMMUNOHISTOCHEMISTRY

Immunohistochemistry was performed on iris ciliary body whole mounts as previously described. ${ }^{14-16}$ Briefly, endogenous peroxidase activity was eliminated by preincubation in PBS, 1\% hydrogen peroxide for 20 minutes. Whole mounts of iris ciliary body were incubated with primary antibodies at $4^{\circ} \mathrm{C}$ overnight. The primary monoclonal antibodies used were DB12 and DB13 (kindly provided by $\mathrm{Dr} P$ van der Meide), both specific to different epitopes of rat IFN- $\gamma \cdot{ }^{17}$ Monoclonal antibody $2 \mathrm{H} 3$ (purchased from the Developmental Studies Hybridoma Bank, Iowa, IA, USA), specific to neurofilaments, ${ }^{18}$ was used as control for neuronal staining. Monoclonal antibodies ED-1, recognising rat monocytes, macrophages, and $90 \%$ of dendritic cells, ED-2, recognising resident connective tissue macrophages (both antibodies kindly provided by Dr C Dijkstra) and OX-6 (Sera-Lab, Sussex), recognising rat MHC class II were used to assess the inflammatory changes in the iris ciliary body. Incubation without primary antibodies served as negative control. No specific staining was observed when primary antibodies were omitted (data not shown). Subsequent incubations with biotinylated sheep antimouse antibody (Amersham Life Science, Amersham) and streptavidin-biotinperoxidase complex (Dako, Glostrup, Denmark) were carried out at room temperature. Staining was performed with 3,3 diaminobenzidine tetrahydrochloride (Sigma, St Louis, MO, USA). Stained whole mounts were placed on gelatin coated slides with the epithelium facing up, dried at room temperature, and embedded in Entellan.

\section{Results}

Injection of LPS induced acute panuveitis, characterised by cellular infiltration of both the anterior segment (according to slit lamp examination) and posterior segment ${ }^{14}{ }^{15}$ of the eye. Staining with ED-1, ED-2, and OX-6 was performed to assess the inflammatory changes in the iris ciliary body. The results of immunostaining with these antibodies of normal and inflamed irises were consistent with previous findings of McMenamin et al. ${ }^{19}$ A network of ED-1, ED-2, and OX-6 positive dendritic cells was found in the normal iris. The number of monocytes/macrophages and MHC class II positive (round and dendritiform) cells in the iris increased immediately after LPS injection, reached peak levels after

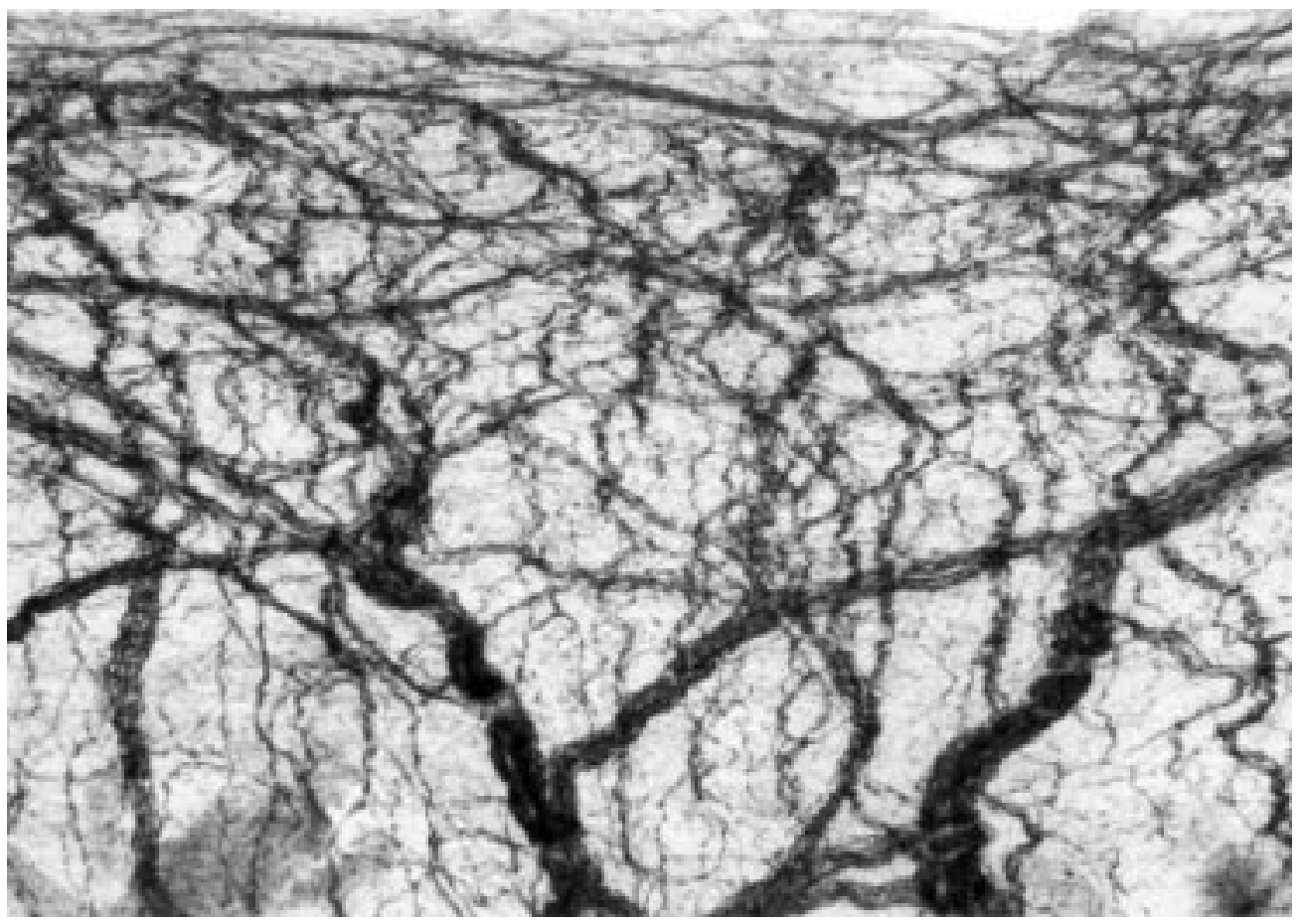

Figure 2 Immunohistochemical staining of an iris whole mount isolated from a control rat with mAbs $2 \mathrm{H3}$. Original magnification, $\times 100$. 
24 hours and returned to preinjection level by day 14.

IFN- $\gamma$ staining was not observed in iris whole mounts of control rats (Fig 1A). LPS injection induced IFN- $\gamma$ immunoreactivity in fibres, from 4 hours to 10 days after injection, although differences in the number of positive irises between DB12 and DB13 staining were observed (Table 1). The strongest staining was observed from 24 to 72 hours (Fig 1B-D), especially at 48 hours, and decreased gradually during following times.

No round or dendritiform DB12 or DB13 positive cells were detected in the iris after LPS injection. The IFN- $\gamma$ positive fibres, which were found either as single fibres or in bundles, formed a dense network in the iris. Both thick and thin bundles were found at the iris base and mid-iris. Thin bundles, intermingled with single fibres, were detected in a dense plexus in the sphincter area. Immunostaining of control irises with $\mathrm{mAb} 2 \mathrm{H} 3$ showed a fibrous network of neurofilaments (Fig 2) similar to the pattern stained by DB12 or DB13 after LPS injection, strongly implying that IFN- $\gamma$ immunoreactivity was present in nerve fibres. The antibodies ED-1, ED2, and OX-6 (all IgG1 isotype) did not reveal the characteristic fibre-like staining pattern as seen with the two monoclonal antibodies against IFN- $\gamma$ (DB12 and DB13; both IgG1 isotype) during EIU indicating that the immunostaining of the nerve fibres was not due to an aspecific interaction with the mouse monoclonal antibodies.

\section{Discussion}

The present study demonstrates IFN- $\gamma$ immunoreactivity in fibres in the iris during EIU in the rat. Immunostaining with the monoclonal anti-IFN- $\gamma$ antibodies DB12 or DB13 showed a staining pattern very similar to that seen with the monoclonal antibody $2 \mathrm{H} 3$, that recognises nerve fibres, and to the staining of sensory nerve fibres with a polyclonal antibody against neurofilament protein. ${ }^{20}$ Other IFN- $\gamma$ positive cells were not detected in the iris, making it unlikely that this cytokine originates from adjacent cells, such as infiltrating $\mathrm{T}$ cells. Together, this strongly suggests that the IFN- $\gamma$ immunoreactive material present in iris nerve fibres may be identical to N-IFN- $\gamma$ reported earlier in other tissues. ${ }^{3-5}$

$\mathrm{N}-\mathrm{IFN}-\gamma$ appears to be a structurally related form of "immune" IFN- $\gamma$, based on antibody binding and biological effects. It was initially detected by immunohistochemistry, using different anti-IFN- $\gamma$ monoclonal antibodies of the "DB" series, in subpopulations of sensory neurons, in perivascular nerve fibres, in certain nerve fibres branching in the central nervous system, ${ }^{3}$ and in sympathetic and parasympathetic ganglion cells. ${ }^{4}$ Some neurons, such as the facial motor neurons normally do not express it but can be induced to produce N-IFN- $\gamma$ after nerve transection. ${ }^{21}{ }^{22}$

The monoclonal antibodies of the DB series were made using immune IFN- $\gamma$ as the antigen and only later was it shown that they reacted with nerve fibres under certain conditions. As far as we know no one has made an antibody using IFN- $\gamma$ like material from nerve fibres as the immunising antigen. Our study is the first to show that IFN- $\gamma$ immunoreactivity is induced in iris neurons after LPS stimulation. Whether LPS stimulates N-IFN- $\gamma$ production elsewhere is not yet known.

IFN- $\gamma$ immunoreactivity in the iris was investigated in the present study by using two monoclonal antibodies directed against different epitopes on immune IFN- $\gamma$. Most prominent staining was observed with the DB13 anti-IFN- $\gamma$ antibody. This may be due to differences in antibody affinity and is in agreement with the findings of other authors who showed that DB13 inhibited antiviral activity of IFN- $\gamma$ better than DB12. ${ }^{17}$

Since iris neurons originate from the trigeminal ganglion, it may be possible that the IFN- $\gamma$ immunoreactive material is produced at this site and transported into the eye. Nerve fibres in the iris, besides being sensory in nature also contain sympathetic and parasympathetic fibres. Olsson et $a l^{5}$ have purified $\mathrm{N}-\mathrm{IFN}-\gamma$ from the trigeminal ganglion of "naive" rats and characterised the functional activity of this cytokine. It was shown that $\mathrm{N}-\mathrm{IFN}-\gamma$ has similar properties as immune IFN- $\gamma$, including induction of MHC class II on macrophages and antiviral activity. ${ }^{5}$ Protein analysis, however, showed that the molecular weight of N-IFN- $\gamma(54-66 \mathrm{kD})$ differs from that of immune IFN- $\gamma(20-25 \mathrm{kD}) .^{521}$

Analysis of spinal ganglia RNA with immune IFN- $\gamma$ probes failed to detect mRNA, ${ }^{21}$ which suggests that N-IFN- $\gamma$ is probably encoded by a gene with no or low DNA homology. Earlier results from our own group ${ }^{6}$ and others ${ }^{7}$ have revealed a variable mRNA expression for IFN- $\gamma$ in the rat iris following systemic LPS administration. Until now it was not clear whether this was $\mathrm{T}$ cell derived or not. McMenamin et al who have performed extensive analysis of the inflammatory infiltrate in the iris during endotoxin induced uveitis observed a massive influx of $\mathrm{T}$ cells. ${ }^{19}$ The fact that we did not observe any IFN- $\gamma$ staining in individual cells may be explained by the fact that the infiltrating $\mathrm{T}$ cells may not yet be activated and therefore do not express IFN- $\gamma$.

Involvement of neuronal factors in EIU has previously been described. Increased levels of the neuropeptides substance P (SP) and pituitary adenylate cyclase activating peptide (PACAP) were detected in aqueous humour during EIU. ${ }^{23}{ }^{24}$ Intraocular injection of these neuropeptides produced certain features of uveitis, ${ }^{24-26}$ implying their inflammatory potential. In contrast with $\mathrm{N}-\mathrm{IFN}-\gamma$, both $\mathrm{SP}$ and PACAP were also detected in iris nerve fibres of "normal" animals. ${ }^{24} 27$

Expression of IFN- $\gamma$ by the nerve fibres may be of great importance in view of the high prevalence of latent herpes viruses in the trigeminal ganglion. ${ }^{28}$ It has been reported that more than $90 \%$ of adults may be infected with herpes simplex virus type $1 .^{29}$ This virus usually establishes latency after primary infection both in animals ${ }^{28}$ and in humans. ${ }^{29}$ Viral reactivation can be triggered by stress and challenges such as fever, ${ }^{29}$ surgery, trauma, ${ }^{28}{ }^{29}$ 
and infection. ${ }^{30}$ IFN- $\gamma$ has antiviral activity $^{2}$ and the presence of IFN- $\gamma$ in neurons may provide the host with a mechanism to suppress reactivation of viruses pre-existing in ganglions.

In summary, our study demonstrates a transient expression of IFN- $\gamma$ immunoreactivity in iris fibres in response to systemic LPS challenge. Although the relevance of IFN- $\gamma$ expression in nerve fibres remains to be elucidated, this finding may have implications for understanding certain mechanisms involved in the pathogenesis of EIU, as well as in other processes such as reactivation of neurotrophic viruses.

Monoclonal antibodies were generous gifts of Dr PH van der Meide, TNO, Rijswijk, Netherlands and Dr C Dijkstra, Free University, Amsterdam, Netherlands. Dr P Yang was supported by a grant from the Guangdong
Province Natural Science Foundation and the Foundation of the Health Ministry of the People's Republic of China.

Dr AF de Vos was supported by a grant of the foundation "Vrienden MS Research".

1 Young HA, Hardy KJ. Role of interferon- $\gamma$ in immune cell regulation. F Leuk Biol 1995;58:373-81.

2 Sen GC. The interferons. In: Remick DG, Friedland JS, eds. Cytokines in health and disease. New York: Marcel Dekker, 1997:199-208.

3 Ljungdahl A, Olsson T, Van der Meide PH, et al. Interferon$\gamma$-like immunoreactivity in certain neurons of the central
and peripheral nervous system. $\mathcal{F}$ Neurosi Res $1989 ; 24$ : and perip.

4 Kiefer R, Kreutzberg GW. Gamma interferon-like immunoreactivity in the rat nervous system. Neuroscience 1990;37: 725-34.

5 Olsson T, Kelic S, Edlund C, et al. Neuronal interferon- $\gamma$ immunoreactive molecule: bioactivities and purification. Eur f Immunol 1994;24:308-14.

6 De Vos AF, Klaren VNA, Kijlstra A. Expression of multiple cytokines and IL-1RA in the uvea and retina during endotoxin-induced uveitis in the rat. Invest Ophthalmol Vis Sci 1994;35:3873-83.

7 Planck SR, Huang XN, Robertson JE, et al. Cytokines mRNA levels in rat ocular tissues after systemic endotoxin treatment. Invest Ophthalmol Vis Sci 1994;35:924-30.

8 Whitcup SM, Rizzo LV, Lai JC, et al. IL-12 inhibits endotoxin-induced inflammation in the eye. Eur f Immuno 1996;26:995-9.

9 De Vos AF, Hoekzema R, Kijlstra A. Cytokines and uveitis, De Vos AF, Hoekzema R, Kijlstra A. Cy
a review. Curr Eye Res 1992;11:581-97.

10 Egwuagu CE, Sztein J, Chan CC, et al. Ectopic expression of gamma interferon in the eyes of transgenic mice induces ocular pathology and MHC class II gene expression. Invest Ophthalmol Vis Sci 1994;35:332-41

11 Geiger K, Howes E, Gallina M, et al. Transgenic mice expressing IFN- $\gamma$ in the retina develop inflammation of the eye and photoreceptor loss. Invest Ophthalmol Vis Sci 1994; 35:2667-81.
12 Kogiso M, Tanouchi Y, Mimura Y, et al. Endotoxin-induced ogiso M, Tanouchi Y, Mimura Y, et al. Endotoxin-induced uveitis in mice. 1 Induction of uveitis and role
lymphocytes. fpn $\mathcal{F}$ Ophthalmol 1992;36:281-90.

13 Okumura A, Mochizuki M, Nishi M, et al. Endotoxininduced uveitis (EIU) in the rat: a study of inflammatory and immunological mechanisms. Int Ophthalmol 1994;49: $51-8$.

14 Yang P, De Vos AF, Kijlstra A. Macrophages in the retina of normal Lewis rats and their dynamics after injection of lipopolysaccharide. Invest Ophthalmol Vis Sci 1996;37:7785.

15 Yang P, De Vos AF, Kijlstra A. Macrophages and MHC class II positive cells in the choroid during endotoxin induced uveitis. Br f Ophthalmol 1997;81:396-401.

16 McMenamin PG, Crewe J, Morrison S, et al. Immunomorphologic studies of macrophages and MHC class IIpositive dendritic cells in the iris and ciliary body of the rat, mouse and human eyes. Invest Ophthalmol Vis Sci 1994;35: 3234-50.

17 Van der Meide PH, Borman AH, Beljaars HG, et al. Isolation and characterization of monoclonal antibodies directed to rat interferon-gamma. Lymphokine Res 1989;8: 439-49.

18 Dodd J, Morton SB, Karagogeos D, et al. Spatial regulation of axonal glycoprotein expression on subsets of embryonic spinal neurons. Neuron 1988;1:105-16.

19 McMenamin PG, Crewe J. Endotoxin-induced uveitis. Kinetics and phenotype of the inflammatory cell infiltrate Kinetics and phenotype of the inflammatory cell infiltrate
and the response of the resident tissue macrophages and and the response of the resident tissue macrophages and
dendritic cells in the iris and ciliary body. Invest Ophthalmol dendritic cells in the iris a
Vis Sci 1995;36:1949-59.

20 Olson L, Lievre CAL, Bjorklund $\mathrm{H}$, et al. The innervation apparatus of the rodent iris. In: Bjorklund A, Hokfelt T, Owman C, eds. The peripheral nervous system. Amsterdam: Elsevier, 1988:545-97.

21 Kiefer R, Haas CA, Kreutzberg GW. Gamma interferon-like immunoreactive material in rat neurons: evidence against a close relationship to gamma interferon. Neuroscience 1991; 45:551-60.

22 Olsson $\mathrm{T}$, Kristensson $\mathrm{K}$, Ljungdahl A, et al. Gammainterferon-like immunoreactivity in axotomized rat motor neurons. F Neurosci 1989;9:3870-5.

23 Herbort CP, Okumura A, Mochizuki M. Endotoxininduced uveitis in the rat. A study of the role of inflammation mediators. Graefes Arch Clin Exp Ophthalmol 1988;226: 553-8.

24 Wang ZY, Alm P, Hakanson R. Distribution and effects of pituitary adenylate cyclase-activating peptide in the rabbit eye. Neuroscience 1995;69:297-308

25 Nishiyama A, Masuda K, Mochizuki M. Ocular effects of substance P. Ұpn f Ophthalmol 1981;25:362-9.

26 Bill A, Stjernschantz J, Mandahl A, et al.. Substance P: release on trigeminal nerve stimulation, effects in the eye. Acta Physiol Scand 1979;106:371-3.

27 Tervo K, Tervo T, Eranko L, et al. Effect of sensory and sympathetic denervation on substance P immunoreactivity in nerve fibres of the rabbit eye. Exp Eye Res 1982;34:57785.

28 Simmons A, Tscharke D, Speck P. The role of immune mechanisms in control of herpes simplex virus infection of the peripheral nervous system. Curr Top Microbiol Immunol 1992;179:32-56.

29 Kaufman HE. Management of herpetic keratitis. In: Bialasiewicz AA, Schaal KP, eds. Infectious diseases of the eye. Buren: Aeolus Press, 1994:194-8.

30 Green MT, Dunkel EC. Herpes simplex virus infections: latency and reactivation. In: Darrell RW, ed. Viral diseases of the eye. Philadelphia: Lea and Febiger, 1985:9-28. 